\title{
ДИСКУССИЯ \\ ПРОФЕССИОНАЛЬНАЯ ПОЗИЦИЯ ПСИХОЛОГА В УСЛОВИЯХ ЗАКОНОДАТЕЛЬНОЙ ДИСКРИМИНАЦИИ «НЕТРАДИЦИОННЫХ» ОТНОШЕНИЙ: ВЫЗОВЫ И ВОЗМОЖНЫЕ ЗАДАЧИ
}

\begin{abstract}
А.А. ЛЕОНТЬЕВА ${ }^{\mathrm{a}}$
${ }^{a}$ Национальный исследовательский университет «Высшая школа экономики», 101000, Россия, Москва, ул. Мясницкая, д. 20
\end{abstract}

После принятия поправок в закон № 436-Ф3 «О защите детей от информации, причиняющей вред их здоровью и развитию» оказалось, что сфера его правоприменения активно апеллирует к области профессиональных знаний психологов. Вопросы «нетрадиционных» отношений и прав человека не сходят с повестки общественного обсуждения, в частности, из-за новостных сообщений об изменениях законодательства в других странах, например по легализации однополых браков. При этом релевантная данному законотворчеству тематика не включена пока в круг тем, которые активно обсуждают специалисты-психологи. Такие дискуссии, как, например, критика разработанной рядом психологов «Концепции информационной безопасности детей», остаются маргинальными. Ответственные редакторы и соредакторы настоящего выпуска сочли важным инициировать проведение «очно-заочного круглого стола» с целью сделать видимыми вызовы и релевантные теме процессы в течение последних трех лет и продвинуться к их комплексной и всесторонней профессиональной оценке.

К участию в заочном этапе дискуссии приглашали рассылкой по профессиональным группам в социальных сетях, а также напрямую обращались к тем, кто связан с психологией сексуальности: в консультировании, исследованиях, экспертизе. В декабре 2015 г. в московском кампусе НИУ ВШЭ прошла очная встреча, по ее итогам некоторые коллеги подготовили тезисы, опубликованные в онлайн-приложении к настоящему выпуску (А. Варга, А. Гизуллина, Д. Гуляев, Д. Исаев, Т. Лапшина, Е. Петрова, M. Травкова). Ниже изложены прозвучавшие на очной встрече реплики присутствовавших и высказывания, развернутые в онлайн-приложении к этому выпуску.

Проблемы экспертной деятельности в реалиях закона обсуждались в нескольких направлениях. Участники встречи сразу согласились, что 
практика экспертизы наличия так называемой пропаганды гомосексуализма не соответствует профессиональному корпусу знаний. В этой связи обсуждались несколько стратегий деятельности ученых. Сергей Ениколопов заявил о важности вести работу по уточнению понятий закона (юристами) и особенно по развитию системы исследований, которые позволили бы экспертам доносить до судебных органов компетентную научно обоснованную позицию. Данила Гуляев высказал сомнение в том, что законодатели и потенциальные обвинители заинтересованы в юридической ясности. Соображения Сергея Ениколопова о востребованности российских исследований по вопросам вариативной сексуальности в целом и психосексуального развития современных подростков в частности весьма актуальны. Тем не менее Юлия Мальцина поставила под вопрос целесообразность «выстраивать академическую машину» вокруг законодательных практик низкого качества, а Анна Леонтьева обратила внимание на то, что задача установления наличия «пропаганды гомосексуализма» принципиально не может решаться на научной основе в силу самой постановки, поэтому развитие психологии сексуальности вряд ли сможет облегчить экспертам работу. Татьяна Лапшина привлекла внимание к косвенным путям преодоления проблем судебной практики в этой сфере. Сделать более адекватной ситуацию для психолога-эксперта смогут развитие системы помощи и просвещения по проблемам ЛГБТКИА и снижение напряжения в этой области. С этим согласилась Анна Леонтьева, предполо- жив, что вопрос «о пропаганде» както отражает отсутствие языка для описания происходящих трансформаций сексуальной идентичности не только в России.

Это созвучно опубликованной в приложении реплике Аннь Гизуллиной, привлекшей внимание к проблеме просвещения, предоставления информации, - по ее оценке, каждый пятый человек в стране имеет отношение к проблеме ЛГБТКИА - и преподавательским задачам, в том числе в системе профессионального образования. Она приводит данные о гомофобии студентов профильных специальностей. В очном обсуждении многие коллеги заметили, что среди тех, кто высказывается по проблеме «пропаганды гомосексуализма» многие оказываются не знакомы с базовыми документами клинической психологии (как DSM-10) либо зачастую не понимают принципов их составления или логики доказательных подходов. Вопрос о просвещении поддержан и в реплике Екатерины Петровой, которая обращает внимание на то, что сведения о современных исследованиях в области семейной и личностной психологии людей с разной сексуальностью просто мало известны. В российском Интернете, например, самой цитируемой остается скандальная и неоднократно опровергнутая единственная работа о негативном влиянии однополого родительства на детей, тогда как огромный корпус работ, лежащий в основе вектора на преодоление гомофобии на всех уровнях в мире, остается совершенно неизвестным и нередко мифологизируется.

Несмотря на научные традиции в области сексологии, сегодня психо- 
логические исследования в области сексуальности, по выражению $E \kappa a-$ терины Петровой, эклектичны и несколько фрагментарны. Анна Гизуллина и Дмитрий Исаев свидетельствуют, что академическая работа по этой тематике в нашей стране встречает препятствия, несмотря на то, что запрос на фундаментальные и культурно-специфичные работы в этой области очень велик (Сергей Ениколопов). Кроме того, оживленное обсуждение вызвали проблемы методологии исследований, так как, по замечанию Натальи Мальшевой, некоторые академические подходы вне феноменологической установки могут оказаться неадекватными исследовательским задачам сообществ в маргинальной позиции; Данила Гуляев высказал опасения по поводу того, что под видом научных развитие могут получить нормализирующие подходы в рамках премордиально понятного «менталитета», с учетом тренда на психологизацию таких понятий, как «нравственность» или «традиционные ценности». Анна Леонтьева заметила, что можно зафиксировать большой разрыв между историями людей (например, приватным обсуждением опыта религиозных ЛГБТКИА-граждан) и дискурсами, призывающими к упрощенным нормативным идеалам в духе консерватизма (например, о несовместимости религиозной веры и гомосексуальности).

В области психологической практики участники согласились с тем, что напряженность вокруг темы сексуальности для самого специалиста не представляет нового вызова и отсылает к общим вопросам компетентности и профессиональной при- годности. Многие поддержали Анну Варгу в ее суждении о том, что скорее актуальной становится правовая защищенность такого консультанта. Виктор Заикин и Татьяна Лапшина заметили, что содержательный вызов, однако, специфичен в работе с несовершеннолетними, например, в школах: так, работа с травлей ребенка требует просвещения в классе ребенка, которое оказывается потенциально рискованным в контексте запретов на «пропаганду».

Многие участники обсуждения высказывались и о социальном контексте настоящих вопросов. Дмитрий Исаев анализирует отношения психологов с обществом и государством/властью, отмечая, что многие этапы развития профессии не пройдены еще на уровне профессионального сообщества. Его высказыванию созвучна реплика Маринь Травковой о тех вызовах, которые представляет законодательство к психологам как к сообществу. Анна Варга привлекает внимание к тому, что особенность сегодняшней ситуации - в криминализации современной российской культуры. Эта криминализация связана и с правами человека (и в этом с ней согласна Анна Гизуллина), и с отношением к проблемам сексуальности в целом. Философ Михаил Немиев отметил, что аргументы, апеллирующие к сакральным текстам, и научные аргументы очень различаются по своей связности, доступности, по способу воздействия. Он говорил о том, что профессионалы во всех развитых странах сталкиваются с вызовами социальных трансформаций, обозначенных как феномен «постсекулярного общества». Ссылки на религиозную 
мораль и аргументация, апеллирующая к сакральным текстам, часто применяются в общественных обсуждениях (и, например, в судах), и ученые так или иначе имеют дело с этим влиянием в обществе.

На этом круглом столе состоялся диалог людей с очень разным опытом (экспертизы, консультирования, обучения, практики), по-разному затронутых происходящим в области под- ростковой психологии, сексуальности, социальной работы. Участники отметили, что совместное определение профессиональной повестки в меняющихся социальных условиях очень востребовано, и согласились с тем, что это движение только начато, а все поставленные проблемы ждут дальнейшей разработки и подготовка специального выпуска журнала хороший шаг в этом направлении.

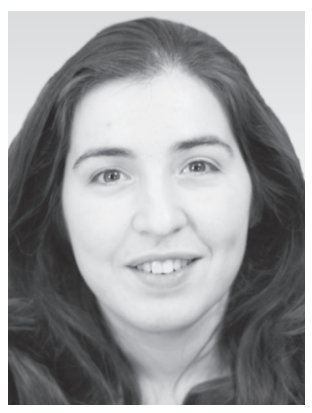

Леонтьева Анна Алексеевна - старший преподаватель, кафедра организационной психологии, департамент психологии, факультет социальных наук, Национальный исследовательский университет «Высшая школа экономики».

Контакты: anna.a.leontieva@gmail.com

Anna A. Leontieva - assistant professor, Department of Organizational Psychology, School of Psychology, Faculty of Social Sciences, National Research University Higher School of Economics. E-mail: anna.a.leontieva@gmail.com 